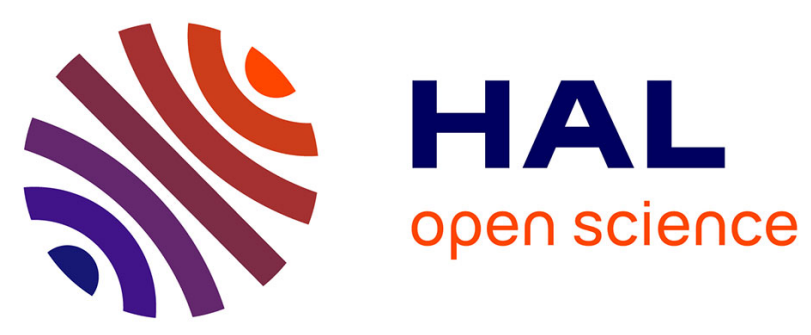

\title{
Regulation of vitamin $D$ receptor function in MEN1-related parathyroid adenomas
}

\author{
Koen M.A. Dreijerink, Radhika A. Varier, Rick van Nuland, Roel \\ Broekhuizen, Gerlof D. Valk, Jacqueline E. van Der Wal, Cornelis J.M. Lips, \\ J. Alain Kummer, H.Th. Marc Timmers
}

\section{To cite this version:}

Koen M.A. Dreijerink, Radhika A. Varier, Rick van Nuland, Roel Broekhuizen, Gerlof D. Valk, et al.. Regulation of vitamin D receptor function in MEN1-related parathyroid adenomas. Molecular and Cellular Endocrinology, 2009, 313 (1-2), pp.1. 10.1016/j.mce.2009.08.020 . hal-00522862

\section{HAL Id: hal-00522862 https://hal.science/hal-00522862}

Submitted on 2 Oct 2010

HAL is a multi-disciplinary open access archive for the deposit and dissemination of scientific research documents, whether they are published or not. The documents may come from teaching and research institutions in France or abroad, or from public or private research centers.
L'archive ouverte pluridisciplinaire HAL, est destinée au dépôt et à la diffusion de documents scientifiques de niveau recherche, publiés ou non, émanant des établissements d'enseignement et de recherche français ou étrangers, des laboratoires publics ou privés. 


\section{Accepted Manuscript}

Title: Regulation of vitamin D receptor function in MEN1-related parathyroid adenomas

Authors: Koen M.A. Dreijerink, Radhika A. Varier, Rick van Nuland, Roel Broekhuizen, Gerlof D. Valk, Jacqueline E. van der Wal, Cornelis J.M. Lips, J. Alain Kummer, H.Th. Marc Timmers

PII: S0303-7207(09)00454-7

DOI:

Reference: doi:10.1016/j.mce.2009.08.020 MCE 7301

To appear in: $\quad$ Molecular and Cellular Endocrinology

Received date: $\quad$ 15-3-2009

Revised date: 24-7-2009

Accepted date: $\quad$ 26-8-2009

Please cite this article as: Dreijerink, K.M.A., Varier, R.A., van Nuland, R., Broekhuizen, R., Valk, G.D., van der Wal, J.E., Lips, C.J.M., Kummer, J.A., Timmers, H.Th.M., Regulation of vitamin D receptor function in MEN1-related parathyroid adenomas, Molecular and Cellular Endocrinology (2008), doi:10.1016/j.mce.2009.08.020

This is a PDF file of an unedited manuscript that has been accepted for publication. As a service to our customers we are providing this early version of the manuscript. The manuscript will undergo copyediting, typesetting, and review of the resulting proof before it is published in its final form. Please note that during the production process errors may be discovered which could affect the content, and all legal disclaimers that apply to the journal pertain. 


\section{Regulation of vitamin D receptor function in MEN1-related parathyroid adenomas}

Koen M.A. Dreijerink ${ }^{\mathrm{a}, \mathrm{b}}$, Radhika A. Varier ${ }^{\mathrm{a}}$, Rick van Nuland ${ }^{\mathrm{a}}$, Roel Broekhuizen ${ }^{\mathrm{c}}$, Gerlof D. Valk $^{\mathrm{b}}$, Jacqueline E. van der Wal ${ }^{\mathrm{d}}$, Cornelis J.M. Lips ${ }^{\mathrm{b}}$, J. Alain Kummer ${ }^{\mathrm{c}, \mathrm{e}}$ and H.Th. Marc Timmers $^{\mathrm{a}}$

${ }^{a}$ Department of Physiological Chemistry, University Medical Center Utrecht, Utrecht, The Netherlands

${ }^{\mathrm{b}}$ Department of Internal Medicine, University Medical Center Utrecht, Utrecht, The Netherlands

${ }^{c}$ Department of Pathology, University Medical Center Utrecht, Utrecht, The Netherlands

${ }^{\mathrm{d}}$ Department of Pathology, University Medical Center Groningen, Groningen, The Netherlands.

${ }^{\mathrm{e}}$ current address: Antonius Ziekenhuis, Nieuwegein, The Netherlands

Correspondence: Prof. Dr. H.Th. Marc Timmers. University Medical Center Utrecht, Department of Physiological Chemistry, STR 3.223, P.O. Box 85060, 3508 AB Utrecht, The Netherlands. Fax: +31 8875 68101. E-mail: H.T.M.Timmers@umcutrecht.nl. 
Key words: Multiple endocrine neoplasia type 1, Menin, Parathyroid adenoma, Vitamin D receptor, Histone methyltransferase, Gene transcription, Histone modification

\begin{abstract}
Multiple endocrine neoplasia type 1 (MEN1) is heriditary syndrome characterised by the occurrence of parathyroid, gastroenteropancreatic and pituitary tumours. The MEN1 gene product, menin, co-activates gene transcription by recruiting histone methyltransferases for lysine 4 of histone H3 (H3K4). We investigated whether in MEN1 tumours global changes in $\mathrm{H} 3 \mathrm{~K} 4$ trimethylation (H3K4me3) occur or whether alterations in gene expression can be observed. By immunohistochemistry we found that global levels of $\mathrm{H} 3 \mathrm{~K} 4 \mathrm{me} 3$ are not affected in MEN1-related parathyroid adenomas. Menin can interact directly with the vitamin $D$ receptor (VDR) and enhance the transcriptional activity of VDR. Messenger RNA levels of VDR target genes CYP24 and KLK6 were significantly lower in MEN1 parathyroid adenomas compared to normal tissue. Thus, aberrant gene expression in MEN1 tumours is not caused by lower global $\mathrm{H} 3 \mathrm{~K} 4 \mathrm{me} 3$, but rather by specific effects on genes that are regulated by menininteracting proteins, such as VDR.
\end{abstract}




\section{Introduction}

Multiple endocrine neoplasia type 1 (MEN1) is an inherited syndrome that is characterised by the occurrence of tumours of the parathyroid glands, the pancreas and duodenum, the pituitary gland, the adrenal glands as well as neuro endocrine tumours of the thymus, lungs and stomach, often at a young age (Brandi et al., 2001). MEN1 is caused by germ line mutations in the MEN1 gene (Chandrasekharappa et al., 1997). To date, more than 450 different germ line mutations have been identified, most of which are clearly inactivating (Lemos and Thakker, 2008). The MEN1 gene is a tumour suppressor gene: loss of the wild type allele is required for a cell to become a tumour cell (Larsson et al., 1988). The MEN1 gene is expressed ubiquitously and encodes the protein menin. Menin is localised in the nucleus and can take part in many cellular processes such as regulation of gene transcription, DNA repair and DNA replication (Lemos and Thakker, 2008). Insight into menin function was obtained by the identification of interacting proteins, which indicate a role in histone modification. In each cell nucleus, roughly two metres of DNA are packaged into small units called nucleosomes. These nucleosomes consist of the core histone proteins $(\mathrm{H} 2 \mathrm{~A}, \mathrm{H} 2 \mathrm{~B}, \mathrm{H} 3$ and $\mathrm{H} 4)$. Menin can influence gene transcription by regulating post-translational modification of the tails of these histone proteins. Menin has been shown to repress gene transcription by attracting histone deacetylase activity (Kim et al., 2003). More recently, menin was found to be an integral component of complexes that contain members of the mixed-lineage leukaemia (MLL) family (Hughes et al., 2004, Yokoyama et al., 2004). MLL proteins possess methyltransferase activity specifically directed at lysine 4 of histone $\mathrm{H} 3$ (H3K4), and especially trimethylation of this residue (H3K4me3) (Ruthenburg et al., 2007). Menin is part of the MLL1 and MLL2, but not of the MLL3 or MLL4 complexes (Lee et al., 2006). The menin-MLL1 histone methyltransferase (HMT) complex was found to be important for $\beta$ catenin regulated transcription of the $c-M y c$ gene and is stabilised by the chromatin-associated protein lens epithelium-derived growth factor (LEDGF) (Sierra et al., 2006, Yokoyama and Cleary, 2008). The menin-MLL1 complex can also activate the expression of several other genes involved in cell proliferation such as the $C D K N 2 C$ and $C D K N 1 B$ cyclin-dependent kinase inhibitor genes and genes involved in cell differentiation such as several homeoboxdomain (Hox) genes (Hughes et al., 2004, Yokoyama et al., 2004, Milne et al., 2005). It has been shown that loss of menin can lead to reduced H3K4me3 at these specific target genes (Karnik et al., 2005). To date, no study has addressed global H3K4me3 levels in MEN1-related tumours.

The receptor for activated vitamin $\mathrm{D}\left(1,25(\mathrm{OH})_{2} \mathrm{D}_{3}\right.$; calcitriol) is a member of the nuclear hormone receptor family. In the presence of ligand, the vitamin D receptor (VDR) can bind to vitamin D-responsive DNA elements and regulate transcription of target genes. In parathyroid cells, $1,25(\mathrm{OH})_{2} \mathrm{D}_{3}$ inhibits parathyroid hormone gene transcription and parathyroid hormone secretion (Demay et al., 1992). Furthermore, $1,25(\mathrm{OH})_{2} \mathrm{D}_{3}$ negatively regulates parathyroid cell proliferation (Bikle, 2009). Low $1,25(\mathrm{OH})_{2} \mathrm{D}_{3}$ levels are associated with secondary hyperparathyroidism in patients with renal failure. Several reports suggest that aberrant VDR function can contribute to parathyroid adenoma formation. VDR null or $1 \alpha$-hydroxylase null (unable to synthesize $1,25(\mathrm{OH})_{2} \mathrm{D}_{3}$ ) mice develop parathyroid hyperplasia (Bouillon et al., 2008). VDR gene polymorphisms are associated with primary hyperparathyroidism and alterations of VDR mRNA and protein levels have been reported to occur in parathyroid adenomas (Carling et al., 1995, Carling et al., 2000, Sudhaker Rao et al., 2000). Parathyroid adenomas are the most common manifestation of MEN1, with a penetrance of almost $100 \%$. Moreover, germ line mutations of the MEN1 gene have been found in patients with familial isolated hyperparathyroidism (FIHP) (Miedlich et al., 2001).

We have previously reported that menin can co-activate nuclear receptor mediated gene transcription (Dreijerink et al., 2006). Reduction of menin levels led to decreased expression 
of estrogen receptor alpha $(\mathrm{ER} \alpha)$ and peroxisome proliferator-activated receptor gamma (PPAR $\gamma$ ) target genes (Dreijerink et al., 2006, Dreijerink et al., 2009). To investigate how loss of menin function can lead to aberrant gene expression in MEN1 tumours, we first determined global H3K4me3 staining in parathyroid tumours. To investigate whether expression of specific menin-HMT target genes is affected in MEN1 tumours, we analysed the interaction between menin and VDR and the expression of VDR target genes in MEN1 parathyroid adenomas. 


\section{Materials and methods \\ Patient material}

Normal parathyroid tissue and parathyroid adenoma samples were obtained from the Department of Pathology/UMCU biobank and from the Department of Pathology/ UMCG and used in accordance with the hospital scientific committee regulations, the Declaration of Helsinki, and the code "Proper Secondary Use of Human Tissue" as installed by the Federation of Biomedical Scientific Societies (www.federa.org/?s=1\&m=78\&p=\&v=4) .

\section{Plasmids and mutagenesis}

Construction of vectors pXJ440hVDR, pXJ440hVDR(DE), Gal4-RXR $\alpha$, Gal4-DBD, pEG202NLS-menin and pBabeHygroMenin has been published (Lavigne et al., 1999, Pijnappel et al., 1993, Zwartjes et al., 2004, Hughes et al., 2004, Dreijerink et al., 2006). The menin expression vector pCDNA3.1M+ was a kind gift from G. Weber. The LexA-menin L264P and L267P mutations were introduced by site-directed mutagenesis using the Quikchange procedure. All constructs were verified by DNA sequence analysis of the complete menin cDNA sequence. The B42-hVDR expression plasmid was constructed in the pJG4-5 vector by PCR amplification of the VDR cDNA, from vector pXJ440hVDR using oligos hVDR-EcoR1-F: GATCATCCGAATTCATGGAGGCAATGGCGGCCA and hVDRXho1-R: GATCATCCCTCGAGTCAGGAGATCTCATTGCCAAA, and inserted using EcoRI and XhoI.

\section{Antibodies and immunoblotting}

Antibodies used were: anti-menin (Bethyl, A300-105A), anti-H3K4me3 (Abcam, ab-8580), anti-histone H3 (Abcam, ab-1791), anti-Gal4 (Santa Cruz, SC-510) and against HA (Roche, 3F10). Immunoblotting was carried out as described before (Dreijerink et al., 2006).

\section{Cell lines, stable and transient protein expression}

Cos7 (African green monkey kidney) cells and 293T (human embryonic kidney) cells were routinely cultured in Dulbecco's modified Eagle's medium (DMEM), supplemented with $10 \%$ fetal bovine serum, $2 \mathrm{mM}$ L-glutamine, $100 \mathrm{U} / \mathrm{ml}$ penicillin and $100 \mu \mathrm{g} / \mathrm{ml}$ streptomycin. Generation of MEN1-/- (MEN1T/T) mouse embryonic fibroblasts (MEFs) has been described (Bertolino et al., 2003). MEFs were maintained in DMEM, containing 10\% fetal bovine serum, $2 \mathrm{mM}$ L-glutamine, $100 \mathrm{U} / \mathrm{ml}$ penicillin and $100 \mu \mathrm{g} / \mathrm{ml}$ streptomycin and $100 \mu \mathrm{M} \beta$-mercaptoethanol. For menin re-expression studies, MEN1-/- MEFs were infected with viruses obtained from Phoenix cells transiently transfected with pBabeHygro or pBabeHygroMenin. Cells were grown in medium containing $500 \mu \mathrm{g} / \mathrm{ml}$ hygromycin and monoclonal cell lines were isolated.

Luciferase reporter experiments in Cos7 cells were carried out as described (Dreijerink et al., 2006). In summary, DNA (750 ng per well, in a 12-well format) was transfected using FuGene 6 reagent (Roche). Transfection mixtures consisted of 200 ng luciferase reporter, 25 ng pCMV-Renilla, 5 ng pXJ440hVDR(DE), 25 ng Gal4-RXR $\alpha$, and supplemented with a maximum of $520 \mathrm{ng}$ pCDNA3.1M+ and/or empty pCDNA3 plasmid. $24 \mathrm{hrs}$ after transfection, the medium was changed to medium containing $100 \mathrm{nM} 1,25(\mathrm{OH})_{2} \mathrm{D}_{3}$ (in ethanol), $1 \mu \mathrm{M}$ 9cis-retinoic acid (in ethanol) or vehicle. Luciferase and Renilla activities were measured after 24 hours. Luciferase assays in MEFs were carried out using Effectine transfection reagent (Qiagen). Transfection mixtures (325 ng per well, in a 12-well format) consisted of $200 \mathrm{ng}$ luciferase reporter, $25 \mathrm{ng}$ pCMV-Renilla, Gal4-DBD, or increasing amounts of pXJ440hVDR(DE), or 50 ng Gal4-p53, supplemented with pCDNA3 plasmid. 24 hours after transfection, the medium was changed to medium containing vehicle or $100 \mathrm{nM} 1,25(\mathrm{OH})_{2} \mathrm{D}_{3}$. 24 hours later, cells were lysed and luciferase and Renilla activities were measured. To be 
able to compare the results from the two cell lines, results are shown as relative luciferase activities corrected for the ligand-independent signal at the appropriate concentration of Gal4VDR, to show the fold induction. The Gal4-p53 result was corrected for the Gal4-DBD control experiment.

\section{Immunohistochemistry}

Formalin-fixed $(10 \%(\mathrm{v} / \mathrm{v})$ formalin for 18 hours), paraffin-embedded tissues from 2 normal parathyroid glands, 7 sporadic (non-familial) and 4 parathyroid adenomas from MEN1 patients were used. All tissues were sampled from surgical specimens within 2 hours after resection. Immunohistochemical staining was essentially performed as previously described using rabbit polyclonal antibodies against menin (dilution 1:100), against $\mathrm{H} 3 \mathrm{~K} 4 \mathrm{me} 3(1: 7,500)$ and against histone H3 (1:15,000) (Strik et al., 2002). The optimal dilution for each antibody was determined by end-point titrations on tissue slides of human tonsil. To ensure specific staining the highest dilution was chosen for each antibody, which still yielded a clear nuclear staining. The tissue sections were subjected to antigen retrieval by boiling in $10 \mathrm{mM}$ sodium citrate buffer $\mathrm{pH} 6$ for 15-20 minutes in a microwave oven. Bound antibodies were visualized with 3,3 '-diaminobenzidine $\left(0.1 \mathrm{mg} / \mathrm{ml}\right.$ in $\left.0.02 \% \mathrm{H}_{2} \mathrm{O}_{2}\right)$ as the chromogen. Negative control slides were stained with non-immune rabbit IgGs.

Normal, diminished or loss of menin, H3K4me3 and Histone H3 staining was determined independently by two experienced pathologists comparing staining intensity of neoplastic cells within the adenoma to the non-neoplastic neuroendocrine cells present in the same slide (often at the rim of the lesion) and to other non-neoplastic cells within the lesion (endothelial and inflammatory cells). The intensity of the staining was scored as: similar (+), weaker $(+/-)$, or negative (-) when the majority of cells $(>75 \%)$ showed such staining intensity.

\section{Co-immunoprecipitations}

$293 \mathrm{~T}$ cells in $60 \mathrm{~mm}$ dishes were transiently transfected with $1 \mu \mathrm{g}$ of pCDNA3.1M+ or pCDNA3 and $2 \mu \mathrm{g}$ of pXJ440hVDR or $6 \mu \mathrm{g}$ of Gal4-DBD. After 24 hours the medium was changed to medium containing vehicle or $100 \mathrm{nM} 1,25(\mathrm{OH})_{2} \mathrm{D}_{3}$. After another 24 hours cells were lysed in buffer A (50 mM Tris- $\mathrm{HCl} \mathrm{pH} 8,10 \%$ glycerol, $100 \mathrm{mM} \mathrm{NaCl}, 10 \mathrm{mM} \mathrm{MgCl} 2$, $0.5 \mathrm{mM}$ PMSF, $1 \%$ protease inhibitor cocktail (Sigma), $1 \mathrm{mM} \mathrm{NaF}, 1 \mathrm{mM} \mathrm{Na}_{3} \mathrm{VO}_{4}$, and 0.5 mM DTT). Dynabeads Protein A was incubated with $2 \mu \mathrm{g}$ of anti-Gal4 antibody in buffer A for $1 \mathrm{hr}$ at $4^{\circ} \mathrm{C}$ and then washed 3 times in buffer A before incubating with lysate for $3 \mathrm{hrs}$ at $4^{\circ} \mathrm{C}$. Subsequently the beads were washed 3 times in buffer A and eluted in sample buffer and proteins retained by the anti-Gal4 antibody were visualised by immunoblot analysis.

\section{Yeast two-hybrid analysis}

EGY48 cells were transformed with the B42-VDR construct and the indicated LexA-menin constructs. Cells were grown overnight at $30^{\circ} \mathrm{C}$ in $2 \%$ galactose- $1 \%$ sucrose containing SC medium lacking the appropriate amino acids and in the presence of vehicle or $100 \mathrm{nM}$ $1,25(\mathrm{OH})_{2} \mathrm{D}_{3}$. Lysates were prepared and the LacZ activity was determined by a liquid $\beta$ galactosidase assay as described previously (Albert et al., 2002).

\section{Analysis of VDR target gene expression}

Frozen sections from 6 normal parathyroid tissue samples, 12 sporadic parathyroid adenomas and 7 parathyroid adenomas from MEN1 patients were used for this analysis. This set was unrelated to the paraffin samples used for immunohistochemistry. After homogenization, RNA from human samples was isolated using the QIAzol lysis reagent (Qiagen). $200 \mathrm{ng}$ of total RNA was used for cDNA synthesis using oligo(dT). Messenger RNA levels were 
analyzed by quantitative PCR on a Chromo4-equipped PCR cycler (Bio-Rad) and normalized against a standard reference cDNA. To ensure identical PCR reaction conditions, for every gene, all PCR reactions from the normal and adenoma samples were performed simultaneously on one 96-well plate. For non-intron spanning primer pairs, PCR reactions were performed on RNA that had not been treated with reverse transcriptase. Primer sequences used are: hCYP24-F: CTACCGCAAAGAAGGCTACG, hCYP24-R:

TCATCACTTCCCCTGGTTTC, hKLK6-F: GATGGTGGTGCTGAGTCTGA, hKLK6-R: GAGGTGTAGAGGGCAGCTTG, hSEMA3B-F: ATGCACCAGTGGGTGTCATA, hSEMA3B-R: TTGTACATGAGGGGGTGGTT, hALOX-F:

TCATCGTGGACTTTGAGCTG, hALOX-R: GACAATCTTGTTGGCCAGGT, hPTH-F: TAGCTCCCAGAGATGCTGGT, hPTH-R: AGCTTTGTCTGCCTCTCCAA, hVDR-F: CCAGTTCGTGTGAATGATGG, hVDR-R: AGATTGGAGAAGCTGGACGA, hCDKN2CF: ACGTCAATGCACAAAATGGA, hCDKN2C-R: CGAAACCAGTTCGGTCTTTC, hCDKN1A-F: GGAAGACCATGTGGACCTGT, hCDKN1A-R:

GGCGTTTGGAGTGGTAGAAA, hCDKN1C-F: CCGGCTAACTCTGAGGACAC, hCDKN1C-R TTGCAGGTCGCTTCCTTATT, hGAPDH-F:

TCTGGTAAAGTGGATATTGTTG, hGAPDH-R: GATGGTGATGGGATTTCC. Mean mRNA levels in sporadic and MEN1 tumours were compared to normal parathyroid samples using a two-sided student's t-test. $\mathrm{P}<0.05$ was considered statistically significant. 


\section{Results}

Analysis of global H3K4me3 levels in MEN1 versus sporadic parathyroid adenomas Observations that menin is an integral part of HMT complexes for H3K4 suggest that aberrant gene expression in MEN1 tumours can either be the result of a general loss of H3K4me3 activity or of target gene-specific effects. To determine whether global H3K4me3 levels are affected in MEN1 tumours, we performed immunohistochemical analysis of sections of sporadic parathyroid adenomas and parathyroid tumours from MEN1 patients. Whereas MEN1 tumours invariably contain mutations in the MEN1 gene, only 20\% of the sporadic parathyroid tumours harbor lesions in MEN1 (Heppner et al., 1997).

As expected we found that compared to normal parathyroid tissue, menin levels were reduced in all four MEN1 tumours. In contrast, menin expression was not affected in most sporadic adenomas with only two samples showing a partial menin down regulation (Table). However, we found no global loss of H3K4me3 levels. Total histone H3 levels that served as an internal control were also found to be equal among the samples as expected (Table). Interestingly, in one sporadic adenoma (Table: sample S6), we found areas within the tumour that showed complete loss of menin expression while H3K4me3 staining was similar throughout the tumour (Figure 1). Together, these observations indicate that global H3K4me3 is not affected in MEN1-related parathyroid adenomas.

\section{Menin can co-activate VDR-mediated transcription via a direct ligand-independent interaction}

Vitamin D signalling is an important regulatory mechanism in the parathyroid gland. As MEN1 patients frequently develop parathyroid adenomas, we were interested to study whether menin can regulate VDR function. For this purpose, luciferase reporter assays were performed. Cos7 cells were transiently transfected with increasing amounts of MEN1 expression vector together with the expression vector for a fusion protein containing the ligand-binding domain of VDR fused to the DNA-binding domain of the yeast Gal4 activator. A thymidine kinase (TK) promoter-luciferase construct with five Gal4 binding sites was used as a reporter gene. Similar to our previous observations, overexpression of menin increased ligand-induced transcription to almost threefold, depending on the amount of menin that was co-transfected (Figure 2A) (Dreijerink et al., 2006). VDR binds to its response elements as a heterodimer with the retinoid X receptor (RXR) (Carlberg et al., 1993). To determine if menin can also interact with RXR, additional luciferase experiments were performed. We found that menin can indeed also co-activate RXR $\alpha$-mediated transcription in the presence of ligand (Figure 2B).

In addition to overexpression experiments we investigated the impact of loss of menin on VDR function. To this end we established derivatives of MEN1-/- mouse embryonic fibroblasts (MEFs) stably transduced with retroviruses containing MEN1 or control sequences. We conducted luciferase assays in these cells using increasing amounts of the Gal4-VDR expression plasmid and the TK promoter luciferase construct. Luciferase assays using expression constructs for Gal4 or Gal4-p53, which have not been reported to interact with menin, were included as controls. Expression levels of the Gal4 constructs were equal between the cell lines as assessed by immunoblotting (data not shown). These transient luciferase assays showed that ligand-dependent VDR function was attenuated in the MEN1-/cells compared to the MEN1 re-expressing cells (Figure 2C). As expected Gal4 and Gal4-p53 dependent transcription did not differ between these cell lines. These results indicate that loss of menin results in lower VDR activity.

To investigate whether menin and VDR can interact directly, we performed coimmunoprecipitation experiments in mammalian cells. Menin and Gal4-VDR expression constructs were co-transfected and cells were treated with $1,25(\mathrm{OH})_{2} \mathrm{D}_{3}$ or vehicle. Figure $2 \mathrm{D}$ 
shows that menin is co-immunoprecipitated with VDR both in the presence and absence of ligand. To strengthen these observations and to study the effects of disease-related MEN1 gene mutations on the interaction yeast two-hybrid experiments were performed using expression constructs for B42-fused VDR and LexA-coupled menin. Figure 2E confirms that menin and VDR can interact in a ligand-independent manner. Two patient-derived MEN1 gene mutations L264P (from a MEN1 family) and L267P (from a FIHP family) caused a clear reduction of the yeast two-hybrid interaction between menin and VDR (Poncin et al., 1999). In conclusion, menin can co-activate VDR-mediated transcription, which most likely involves a direct interaction between menin and VDR proteins.

\section{Expression of VDR target genes in MEN1 parathyroid adenomas}

Parathyroid adenoma is the most common manifestation of MEN1. VDR has an important role in parathyroid function. Having established that menin can act as a VDR co-activator and that MEN1 gene mutations can lead to disruption of the menin-VDR interaction, we reasoned that in parathyroid adenomas from MEN1 patients VDR target gene expression may be affected. The only known target gene for VDR in parathyroid adenomas is the $1,25(\mathrm{OH})_{2} \mathrm{D}_{3}$ inactivation enzyme 25-hydroxyvitamin $\mathrm{D}_{3}$-24-hydroxylase (CYP24) (Correa et al., 2002). A large set of VDR target genes was identified in a large-scale microarray study in SCC25 oral tumour cells (Wang et al., 2005). We screened inducibility of these genes by $1,25(\mathrm{OH})_{2} \mathrm{D}_{3}$ in MCF-7 cells, a cell type in which menin was demonstrated to be important for nuclear receptor function (Dreijerink et al., 2006). We found that besides CYP24, one other gene called kallikrein 6 (KLKO) could be induced (data not shown). KLK6 is a serine protease that is expressed in the parathyroid gland (Petraki et al., 2001). Two other possible target genes that could not be induced in MCF-7 cells, semaphorin 3B (SEMA3B) and arachidonic acid lipoxygenase $5(A L O X)$ were also included in the analysis, as well as the $V D R$ gene itself and the $P T H$ gene, which is negatively regulated by $1,25(\mathrm{OH})_{2} \mathrm{D}_{3}$ (Demay et al., 1992). We found that mRNA levels of $C Y P 24$ were lower but not significantly reduced in sporadic parathyroid adenomas compared to normal parathyroid tissue $(\mathrm{P}=0.09)$ (Figure 3A). However, in the MEN1 parathyroid adenomas the presence of $C Y P 24$ and KLK6 mRNA is significantly lower $(\mathrm{P}=0.03, \mathrm{P}=0.04$ respectively) (Figure $3 \mathrm{~A})$. In this context, the SEMA3, ALOX, PTH and VDR mRNA levels did not differ (Figure 3B).

The $C D K N 2 C$ and $C D K N 1 B$ cyclin-dependent kinase inhibitor genes encoding $\mathrm{p} 18^{\mathrm{INK} 4 \mathrm{c}}$ and p $27^{\text {Kip } 1}$ are well established menin target genes (Milne et al., 2005). Cyclin-dependent kinase inhibiting proteins exert anti-proliferative effects by blocking cyclin-dependent kinaseregulated cell cycle progression. These genes have all been reported to be regulated by VDR. $1,25(\mathrm{OH})_{2} \mathrm{D}_{3}$ was shown to induce $\mathrm{p} 18^{\mathrm{INK} 4 \mathrm{c}}$ protein levels in a squamous cell tumour cell line (Gedlicka et al., 2006). Saramaki et al. showed that VDR can be present on the CDKN1A (encoding p $21^{\text {Wafl/Cip1 }}$ ) promoter on VDR responsive elements (Saramaki et al., 2006). Cheng et al. have reported that VDR can bind to the CDKN1B promoter via the Sp1 transcription factor (Cheng et al., 2006). Previously, Correa Buchwald et al. reported reduced $C D K N 2 \mathrm{C}$, $C D K N 1 A$ and $C D K N 1 B$ mRNA levels in sporadic parathyroid adenomas (Buchwald et al., 2004). We also performed RT-PCR analysis of mRNA levels of these CDKI genes in our series of sporadic and MEN1 parathyroid adenomas. We found that $C D K N 2 C$ levels were not altered, $C D K N 1 A$ mRNA was expressed significantly lower in sporadic tumours $(\mathrm{P}=0.004)$ and $C D K N 1 B$ was significantly reduced both in sporadic and in MEN1-related parathyroid adenomas compared to normal parathyroid tissue $(\mathrm{P}=0.004$ and $\mathrm{P}=0.01)$ (Figure 4). Taken together, we found $C Y P 24$ and KLK6 mRNA levels are reduced in parathyroid adenomas in MEN1 patients. $C D K N 1 A$ was lower in sporadic adenomas and $C D K N 2 C$-levels were attenuated in both sporadic and MEN1-related adenomas. 


\section{Discussion}

In this report, we show that global H3K4me3 levels are not affected in MEN1 parathyroid adenomas. Further, our results show that menin can act as a co-activator for VDR-mediated transcription. Messenger RNA levels of several VDR target genes are reduced in MEN1 patient-derived parathyroid adenomas.

\section{Loss of MEN1 does not affect global H3K4me3}

Global loss of H4K20 trimethylation and H4K16 acetylation has been observed in various tumours (Fraga et al., 2005). Distinct global alterations of histone modifications were reported to be prognostically relevant in prostate carcinomas (Seligson et al., 2005). H3K4 trimethylation levels however, were not assessed in these studies. Since there are many methyltransferase complexes, we hypothesized that it is not likely that in the absence of menin in a cell global loss of H3K4 trimethylation occurs (Ruthenburg et al., 2007). Indeed, transient knockdown of menin by siRNA oligos in MCF-7 breast cancer cells did not lead to loss of H3K4me3 (Dreijerink et al., 2006). However, in pancreatic islets from $M E N 1+/-$ mice, Karnik et al. showed reduced total H3K4me3 levels compared to MEN1+/+ mice (Karnik et al., 2005). Our results indicate that loss of menin expression does not affect global H3K4me3 staining in parathyroid tumours. Although these effects could be tissue-specific, we believe that it is more likely that the changes in gene expression which have been observed in vitro and in MEN1 tumours are the result of gene-specific actions of menin. This notion is supported by a recent report that showed MEN1 tumour specific alterations in Hox gene expression compared to non-MEN1 parathyroid adenomas (Shen et al., 2008). This target gene-specificity may be the result of the affinity of the menin HMT complex for other transcriptional regulators such as nuclear receptors, $\beta$-catenin or other chromatin-binding factors such as LEDGF (Sierra et al., 2006, Yokoyama and Cleary, 2008).

\section{Menin co-activates VDR-mediated transcription}

We have shown previously that menin can stimulate ER $\alpha$ and PPAR $\gamma$-mediated transcription and that menin is important for recruiting methyltransferase activity to ER $\alpha$ target genes (Dreijerink et al., 2006, Dreijerink et al., 2009). In this report, both in overexpression expression experiments and in MEN1-/- MEFs, we show that menin can also co-activate VDR-mediated transcription. Although we did not analyse the mechanism for VDR coactivation in much detail, based on analogy with ER $\alpha$ and PPAR $\gamma$ regulation we suggest that recruitment of menin by the activated VDR is responsible for elevated H3K4me3 levels of VDR target promoters. Interestingly, both immunoprecitation experiments and yeast twohybrid studies show that the interaction between menin and VDR is largely ligand-

independent similar to the interaction between menin and PPAR $\gamma$. In contrast, menin acts in a ligand-dependent fashion with ER $\alpha$ and $\mathrm{RXR} \alpha$ (Dreijerink et al., 2006, Dreijerink et al., 2009). Further structural analysis is required to be able to determine the exact nature of the menin-nuclear receptor interaction.

\section{Altered expression of VDR target genes in MEN1 parathyroid adenomas}

We analysed a series of MEN1 patient-derived parathyroid adenomas to find that expression of two VDR target genes CYP24 and KLK6 was significantly lower in MEN1 tumours. In sporadic adenomas slightly lower levels of $C Y P 24$ mRNA (but not significant $\mathrm{P}=0.09$ ) were observed. Previously, Correa et al. reported a significant reduction in CYP24 mRNA levels in sporadic parathyroid adenomas (Correa et al., 2002). The size of our series may have been a limiting factor for showing reduced CYP24 in the sporadic adenomas. Therefore, reduced expression of VDR target genes may not be restricted to MEN1 parathyroid tumours. As MEN1 gene mutations are also found in about $20 \%$ of sporadic parathyroid adenomas, 
MEN1-related and sporadic adenomas may share a common pathway of development (Heppner et al., 1997). A large study aimed to define mRNA expression profiles that could differentiate between several types of parathyroid adenomas showed no differences between sporadic and MEN1-related tumours (Haven et al., 2004). However, the CYP24, KLK6 and CDKI genes were not included in that analysis (Carola Haven, Paul Eilers and Hans Morreau, personal communication).

Interestingly, expression of the $P T H$ gene that is negatively regulated by VDR was not altered in the adenomas. It is known that menin can be involved in TGF- $\beta$-mediated down regulation of PTH production in cell lines, which makes it even more unlikely that the activating menin HMT complex is present on the PTH gene promoter (Sowa et al., 2004).

There have been conflicting reports on the expression of VDR in parathyroid adenomas. Initial reports showed that vitamin D uptake was higher in parathyroid adenomas compared to cases of secondary hyperplasia and that VDR levels were similar in adenomas compared to normal tissue (Korkor, 1987, Trydal et al., 1992). More recent studies showed reduced levels of VDR mRNA in parathyroid adenomas and reduced immunostaining (Carling et al., 2000, Sudhaker Rao et al., 2000). In our series, mean VDR mRNA levels (as determined by quantitative RT-PCR) did not differ significantly between the three groups. Nevertheless, expression of the VDR target genes CYP24 and KLK6 was found reduced in MEN1 adenomas. We analysed mRNA levels of the several CDKI genes. In sporadic adenomas we found reduced expression of $C D K N 1 A$ and $C D K N 1 B$. In MEN1 adenomas, we found only reduced expression of $C D K N 1 C$. These findings are in accordance with a recent report by Correa Buchwald et al., who found that in sporadic parathyroid adenomas $C D K N 1 C$ was significantly down regulated (Buchwald et al., 2004). Although the CDKI genes have been described as VDR targets, in our MCF-7 system expression of these genes was not induced after a six hour stimulation with $1,25(\mathrm{OH})_{2} \mathrm{D}_{3}$ (data not shown). It thus remains unclear if the reduced transcription of these genes is related to altered VDR activity in parathyroid adenomas.

These are the first data to support a role for aberrant nuclear receptor function in MEN1 tumour formation. Profiling of nuclear receptor expression in other MEN1 lesions will lead to better understanding of MEN1 tumourigenesis. As nuclear receptors are potential targets for novel drugs, restoration of nuclear receptor function or of histone modifications may prove beneficial for future therapeutic strategies for MEN1 patients. 
Table Immunohistochemical analysis of sporadic (S) and MEN1-related (M) parathyroid adenomas, compared to normal parathyroid tissue $(\mathrm{N})$.

$\mathrm{H} 3 \mathrm{~K} 4 \mathrm{me} 3$

Histone H3

$\mathrm{N}-2$

$\mathrm{S}-1$

S-2

$\mathrm{S}-3$

S-4

S-5

S-6

S-7

M-1

M-2

$+$

$+$

$+$

$+$

$+$

$+$

$+$

$+$

$+$

$+/-$

$+/-$

$+/-$

M-3

M-4

$+$

$+$

$+$

$+$

$+$

$+$

$+$

$+$

$+/-$

$+$

$+$

$+$ 


\section{Figure legends \\ Figure 1}

Loss of menin expression in a part of a sporadic parathyroid adenoma does not lead to reduced $\mathrm{H} 3 \mathrm{~K} 4 \mathrm{me} 3$. Immunohistochemistry was performed on sections of a sporadic parathyroid adenoma using antibodies directed at menin (left panel, compare left and right) and $\mathrm{H} 3 \mathrm{~K} 4 \mathrm{me} 3$ (right panel, compare left and right). Total histone H3 levels did not differ between the menin positive and negative areas (not shown).

\section{Figure 2}

Menin can co-activate VDR and RXR-mediated transcription and interact directly with VDR. A. Increasing amounts of a MEN1 expression construct were co-transfected together with a Gal4-VDR(DE) construct and a Gal4-TK-driven firefly luciferase reporter vector in Cos7 cells. Cells were treated with $100 \mathrm{nM} 1,25(\mathrm{OH})_{2} \mathrm{D}_{3}$ or vehicle for 24 hours. A CMV promoter-driven Renilla luciferase construct was co-transfected for normalisation. Results are shown as Firefly/ Renilla luciferase ratios. Error bars indicate SD. B. Menin was cotransfected together with a Gal4-RXR $\alpha$ construct in luciferase assays similar to panel A. Cells were treated with $1 \mu \mathrm{M}$ 9-cis-retinoic acid or vehicle for 24 hours. C. Luciferase assays using Gal4-VDR(DE) and Gal4-TK luciferase constructs were performed in MEN1-/- MEFs that had either been transduced with a control or with a MEN1 expression virus. Gal4-DNA binding domain(DBD) and Gal4-p53 were used as controls. Error bars indicate SD. EV: empty vector. D. Co-immunoprecipitation of Gal4-VDR and menin. 293T cells were transiently transfected with menin expression constructs and Gal4-VDR (in the presence or

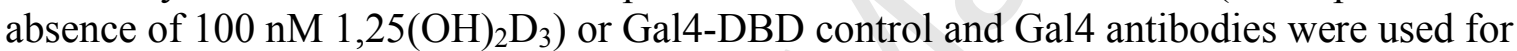
immunoprecipitation. Immunoblot analysis of input and anti-Gal4 immunoprecipitates are shown. Asterisks indicate non-specific bands detected by the Gal4-antibody. E. Yeast twohybrid experiments were performed using a B42 fusion proteins with hVDR and LexAproteins fused to wild type menin or two disease-related MEN1 mutations L264P and L267P. Yeast cells were treated with $100 \mathrm{nM} 1,25(\mathrm{OH})_{2} \mathrm{D}_{3}$ or vehicle for 12 hours. Relative $\beta$ galactosidase activities are shown. Error bars indicate SD. Immunoblot analysis of yeast lysates shows equal expression of the LexA-menin fusion proteins and of B42-HA-VDR.

\section{Figure 3}

Analysis of expression of VDR target genes in 5 normal parathyroid tissues, 12 sporadic adenomas and 7 MEN1-related adenomas. A. Expression of CYP24 and KLK6 gene mRNA relative to GAPDH mRNA levels was assessed by quantitative RT-PCR. Means are indicated by horizontal bars. * indicates statistical significance $(\mathrm{P}<0.05)$ compared to normal parathyroid tissue using a two-sided student's t-test. B. Messenger RNA levels of SEMA3B, $A L O X, P T H$ and $V D R$.

\section{Figure 4}

Messenger RNA levels of cyclin-dependent kinase inhibitor genes differ between normal parathyroid tissue and adenomas. In 5 normal parathyroid samples, 12 sporadic parathyroid adenomas and 7 MEN1 related adenomas, mRNA levels of the CDKI genes $C D K N 2 C$, $C D K N 1 A$ and $C D K N 1 B$ were measured using quantitative RT-PCR relative to GAPDH. * indicates statistical significance $(\mathrm{P}<0.05)$ as in figure 3 . 


\section{Acknowledgement}

We thank the members of the Timmers laboratory, especially F. van Werven, for advice. We thank the UMC-U Biobank (A. Gijsbers-Bruggink) for assistance in collecting human samples. MEN1 -/- MEFs were kindly provided by C. Zhang (University of Lyon, France). We are grateful to G. Folkers (Utrecht University, The Netherlands), G. Mengus (IGBMC, Strasbourg, France) and G. Weber (University of Tours, France) for providing plasmids and to C. Haven, P. Eilers and H. Morreau, (Leiden University Medical Center, The Netherlands) for sharing microarray data.

This work is supported by the Netherlands Organization for Health Research and Development (ZonMw; AGIKO 920-03-231 to CL, HT and KD) and the Netherlands Proteomics Center (to HT and KD). 


\section{References}

Albert, T. K., Hanzawa, H., Legtenberg, Y. I., de Ruwe, M. J., van den Heuvel, F. A., Collart, M. A., Boelens, R. and Timmers, H. T. (2002) Embo J, 21, 355-64.

Bertolino, P., Radovanovic, I., Casse, H., Aguzzi, A., Wang, Z. Q. and Zhang, C. X. (2003) Mech Dev, 120, 549-60.

Bikle, D. (2009) J Clin Endocrinol Metab, 94, 26-34.

Bouillon, R., Carmeliet, G., Verlinden, L., van Etten, E., Verstuyf, A., Luderer, H. F., Lieben, L., Mathieu, C. and Demay, M. (2008) Endocr Rev, 29, 726-76.

Brandi, M. L., Gagel, R. F., Angeli, A., Bilezikian, J. P., Beck-Peccoz, P., Bordi, C., ConteDevolx, B., Falchetti, A., Gheri, R. G., Libroia, A., Lips, C. J., Lombardi, G., Mannelli, M., Pacini, F., Ponder, B. A., Raue, F., Skogseid, B., Tamburrano, G., Thakker, R. V., Thompson, N. W., Tomassetti, P., Tonelli, F., Wells, S. A., Jr. and Marx, S. J. (2001) J Clin Endocrinol Metab, 86, 5658-71.

Buchwald, P. C., Akerstrom, G. and Westin, G. (2004) Clin Endocrinol (Oxf), 60, 389-93.

Carlberg, C., Bendik, I., Wyss, A., Meier, E., Sturzenbecker, L. J., Grippo, J. F. and Hunziker, W. (1993) Nature, 361, 657-60.

Carling, T., Kindmark, A., Hellman, P., Lundgren, E., Ljunghall, S., Rastad, J., Akerstrom, G. and Melhus, H. (1995) Nat Med, 1, 1309-11.

Carling, T., Rastad, J., Szabo, E., Westin, G. and Akerstrom, G. (2000) J Clin Endocrinol Metab, 85, 2000-3.

Chandrasekharappa, S. C., Guru, S. C., Manickam, P., Olufemi, S. E., Collins, F. S., EmmertBuck, M. R., Debelenko, L. V., Zhuang, Z., Lubensky, I. A., Liotta, L. A., Crabtree, J. S., Wang, Y., Roe, B. A., Weisemann, J., Boguski, M. S., Agarwal, S. K., Kester, M. B., Kim, Y. S., Heppner, C., Dong, Q., Spiegel, A. M., Burns, A. L. and Marx, S. J. (1997) Science, 276, 404-7.

Cheng, H. T., Chen, J. Y., Huang, Y. C., Chang, H. C. and Hung, W. C. (2006) J Cell Biochem, 98, 1450-6.

Correa, P., Segersten, U., Hellman, P., Akerstrom, G. and Westin, G. (2002) J Clin Endocrinol Metab, 87, 5826-9.

Demay, M. B., Kiernan, M. S., DeLuca, H. F. and Kronenberg, H. M. (1992) Proc Natl Acad Sci U S A, 89, 8097-101.

Dreijerink, K. M., Mulder, K. W., Winkler, G. S., Hoppener, J. W., Lips, C. J. and Timmers, H. T. (2006) Cancer Res, 66, 4929-35.

Dreijerink, K. M., Varier, R. A., van Beekum, O., Jeninga, E. H., Hoppener, J. W., Lips, C. J., Kummer, J. A., Kalkhoven, E. and Timmers, H. T. (2009) Mol Cell Biol.

Fraga, M. F., Ballestar, E., Villar-Garea, A., Boix-Chornet, M., Espada, J., Schotta, G., Bonaldi, T., Haydon, C., Ropero, S., Petrie, K., Iyer, N. G., Perez-Rosado, A., Calvo, E., Lopez, J. A., Cano, A., Calasanz, M. J., Colomer, D., Piris, M. A., Ahn, N., Imhof, A., Caldas, C., Jenuwein, T. and Esteller, M. (2005) Nat Genet, 37, 391-400.

Gedlicka, C., Hager, G., Weissenbock, M., Gedlicka, W., Knerer, B., Kornfehl, J. and Formanek, M. (2006) J Oral Pathol Med, 35, 472-8.

Haven, C. J., Howell, V. M., Eilers, P. H., Dunne, R., Takahashi, M., van Puijenbroek, M., Furge, K., Kievit, J., Tan, M. H., Fleuren, G. J., Robinson, B. G., Delbridge, L. W., Philips, J., Nelson, A. E., Krause, U., Dralle, H., Hoang-Vu, C., Gimm, O., Morreau, H., Marsh, D. J. and Teh, B. T. (2004) Cancer Res, 64, 7405-11.

Heppner, C., Kester, M. B., Agarwal, S. K., Debelenko, L. V., Emmert-Buck, M. R., Guru, S. C., Manickam, P., Olufemi, S. E., Skarulis, M. C., Doppman, J. L., Alexander, R. H., Kim, Y. S., Saggar, S. K., Lubensky, I. A., Zhuang, Z., Liotta, L. A., 
Chandrasekharappa, S. C., Collins, F. S., Spiegel, A. M., Burns, A. L. and Marx, S. J. (1997) Nat Genet, 16, 375-8.

Hughes, C. M., Rozenblatt-Rosen, O., Milne, T. A., Copeland, T. D., Levine, S. S., Lee, J. C., Hayes, D. N., Shanmugam, K. S., Bhattacharjee, A., Biondi, C. A., Kay, G. F., Hayward, N. K., Hess, J. L. and Meyerson, M. (2004) Mol Cell, 13, 587-97.

Karnik, S. K., Hughes, C. M., Gu, X., Rozenblatt-Rosen, O., McLean, G. W., Xiong, Y., Meyerson, M. and Kim, S. K. (2005) Proc Natl Acad Sci U S A, 102, 14659-64.

Kim, H., Lee, J. E., Cho, E. J., Liu, J. O. and Youn, H. D. (2003) Cancer Res, 63, 6135-9. Korkor, A. B. (1987) N Engl J Med, 316, 1573-7.

Larsson, C., Skogseid, B., Oberg, K., Nakamura, Y. and Nordenskjold, M. (1988) Nature, 332, 85-7.

Lavigne, A. C., Mengus, G., Gangloff, Y. G., Wurtz, J. M. and Davidson, I. (1999) Mol Cell Biol, 19, 5486-94.

Lee, S., Lee, D. K., Dou, Y., Lee, J., Lee, B., Kwak, E., Kong, Y. Y., Lee, S. K., Roeder, R.

G. and Lee, J. W. (2006) Proc Natl Acad Sci U S A, 103, 15392-7.

Lemos, M. C. and Thakker, R. V. (2008) Hum Mutat, 29, 22-32.

Miedlich, S., Lohmann, T., Schneyer, U., Lamesch, P. and Paschke, R. (2001) Eur J Endocrinol, 145, 155-60.

Milne, T. A., Hughes, C. M., Lloyd, R., Yang, Z., Rozenblatt-Rosen, O., Dou, Y., Schnepp, R. W., Krankel, C., Livolsi, V. A., Gibbs, D., Hua, X., Roeder, R. G., Meyerson, M. and Hess, J. L. (2005) Proc Natl Acad Sci U S A, 102, 749-54.

Petraki, C. D., Karavana, V. N., Skoufogiannis, P. T., Little, S. P., Howarth, D. J., Yousef, G. M. and Diamandis, E. P. (2001) J Histochem Cytochem, 49, 1431-41.

Pijnappel, W. W., Hendriks, H. F., Folkers, G. E., van den Brink, C. E., Dekker, E. J., Edelenbosch, C., van der Saag, P. T. and Durston, A. J. (1993) Nature, 366, 340-4.

Poncin, J., Abs, R., Velkeniers, B., Bonduelle, M., Abramowicz, M., Legros, J. J., Verloes, A., Meurisse, M., Van Gaal, L., Verellen, C., Koulischer, L. and Beckers, A. (1999) Hum Mutat, 13, 54-60.

Ruthenburg, A. J., Allis, C. D. and Wysocka, J. (2007) Mol Cell, 25, 15-30.

Saramaki, A., Banwell, C. M., Campbell, M. J. and Carlberg, C. (2006) Nucleic Acids Res, 34, 543-54.

Seligson, D. B., Horvath, S., Shi, T., Yu, H., Tze, S., Grunstein, M. and Kurdistani, S. K. (2005) Nature, 435, 1262-6.

Shen, H. C., Rosen, J. E., Yang, L. M., Savage, S. A., Burns, A. L., Mateo, C. M., Agarwal, S. K., Chandrasekharappa, S. C., Spiegel, A. M., Collins, F. S., Marx, S. J. and Libutti, S. K. (2008) Endocr Relat Cancer, 15, 267-75.

Sierra, J., Yoshida, T., Joazeiro, C. A. and Jones, K. A. (2006) Genes Dev, 20, 586-600.

Sowa, H., Kaji, H., Kitazawa, R., Kitazawa, S., Tsukamoto, T., Yano, S., Tsukada, T., Canaff, L., Hendy, G. N., Sugimoto, T. and Chihara, K. (2004) Cancer Res, 64, 2222-8.

Strik, M. C., Bladergroen, B. A., Wouters, D., Kisiel, W., Hooijberg, J. H., Verlaan, A. R., Hordijk, P. L., Schneider, P., Hack, C. E. and Kummer, J. A. (2002) J Histochem Cytochem, 50, 1443-54.

Sudhaker Rao, D., Han, Z. H., Phillips, E. R., Palnitkar, S. and Parfitt, A. M. (2000) Clin Endocrinol (Oxf), 53, 373-81.

Trydal, T., Varhaug, J. E., Myking, A., Aksnes, L., Aakvaag, A. and Aarskog, D. (1992) Acta Endocrinol (Copenh), 127, 407-12.

Wang, T. T., Tavera-Mendoza, L. E., Laperriere, D., Libby, E., MacLeod, N. B., Nagai, Y., Bourdeau, V., Konstorum, A., Lallemant, B., Zhang, R., Mader, S. and White, J. H. (2005) Mol Endocrinol, 19, 2685-95.

Yokoyama, A. and Cleary, M. L. (2008) Cancer Cell, 14, 36-46. 
Yokoyama, A., Wang, Z., Wysocka, J., Sanyal, M., Aufiero, D. J., Kitabayashi, I., Herr, W. and Cleary, M. L. (2004) Mol Cell Biol, 24, 5639-49.

Zwartjes, C. G., Jayne, S., van den Berg, D. L. and Timmers, H. T. (2004) J Biol Chem, 279, 10848-54. 


\section{Dreijerink Figure 1}

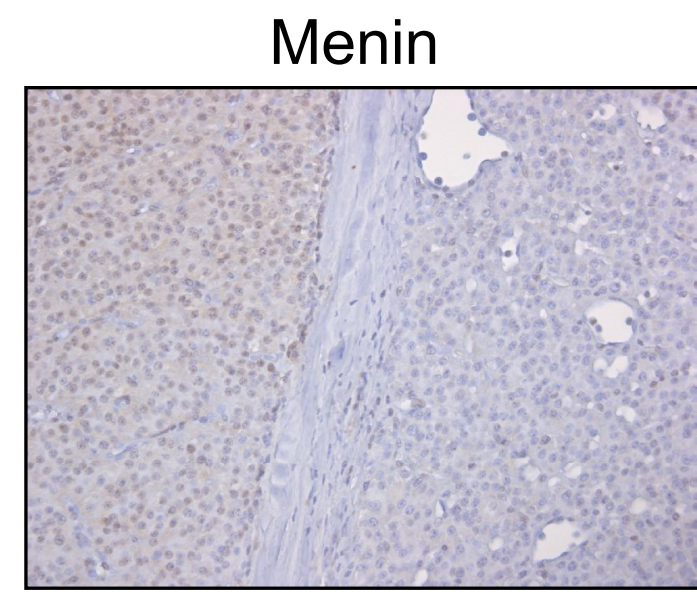

H3K4me3

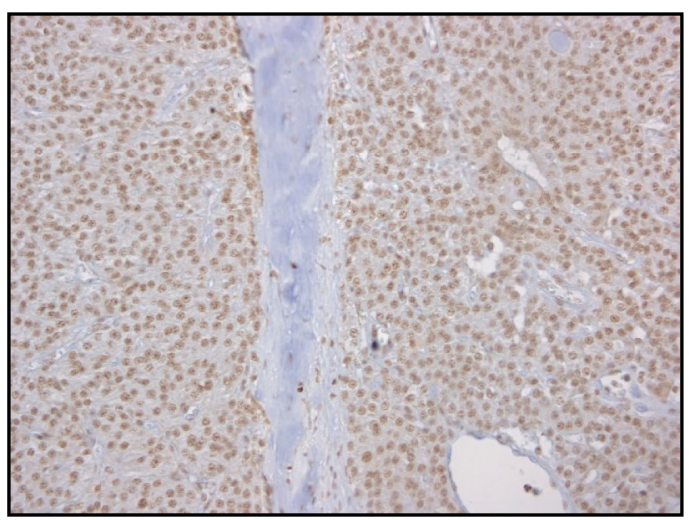




\section{Dreijerink Figure 2}

A

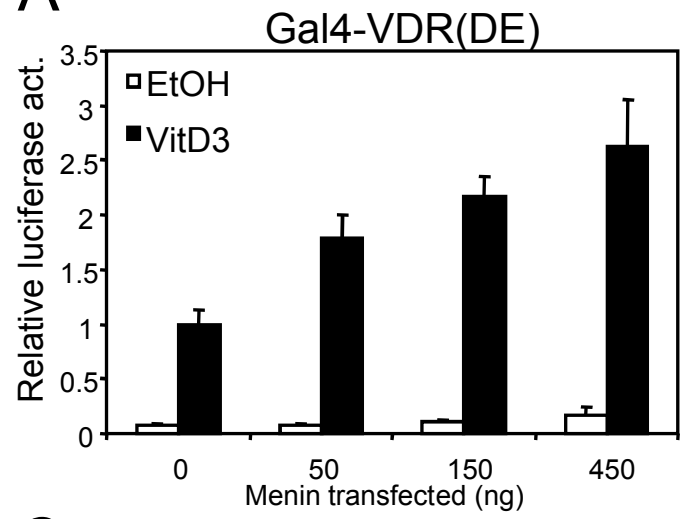

C
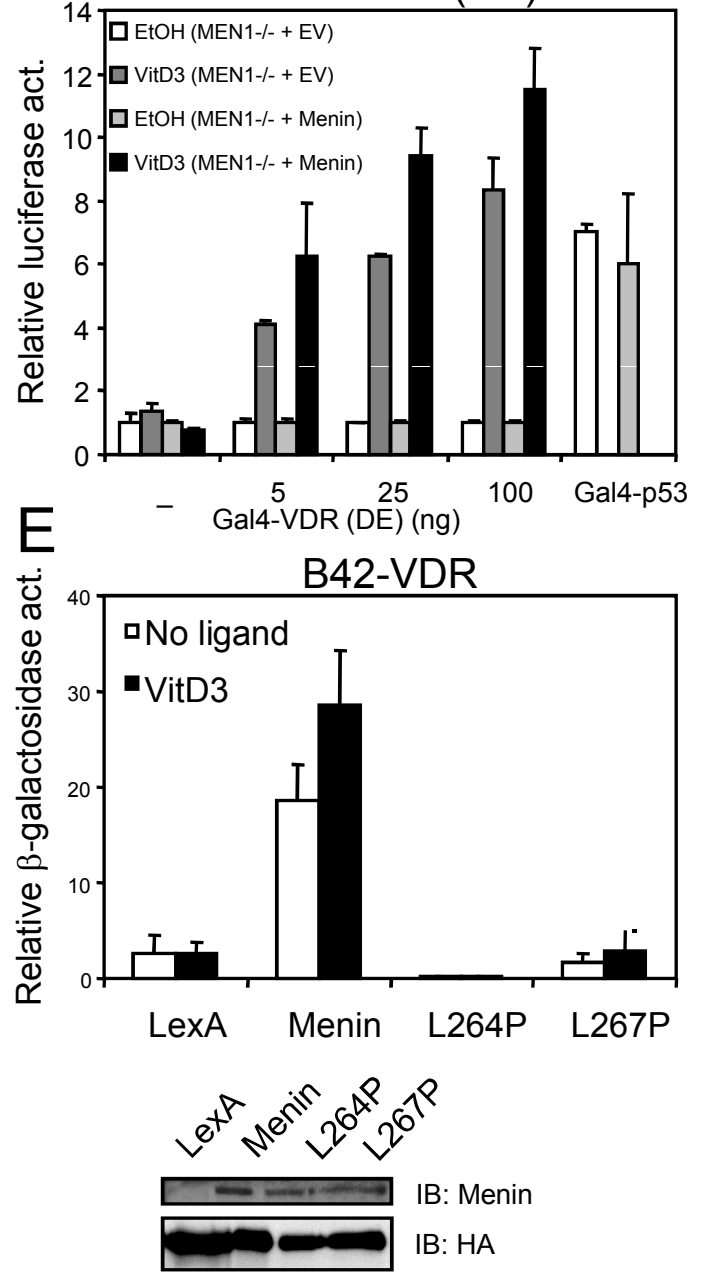

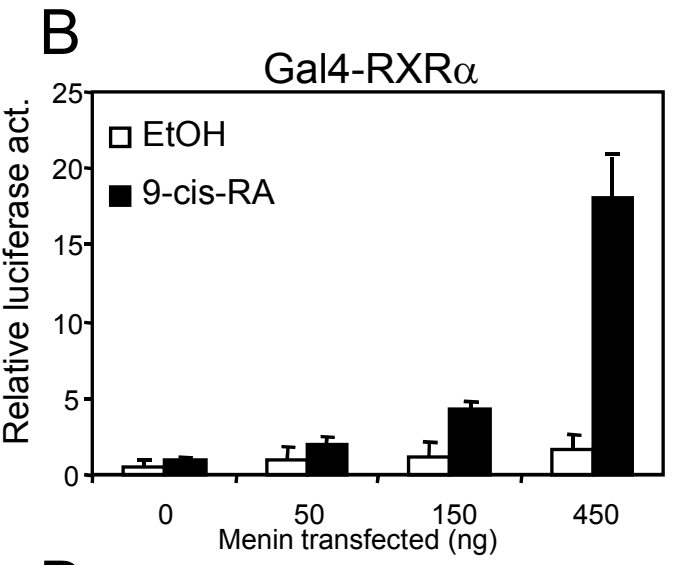

D

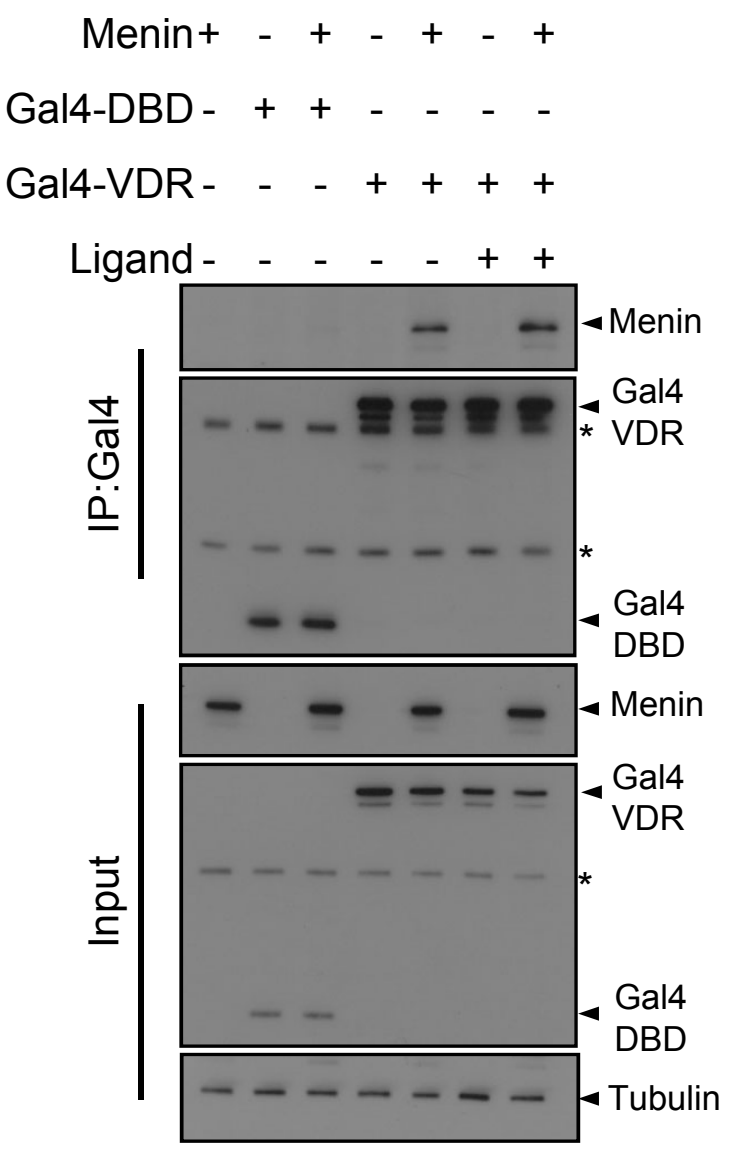




\section{Dreijerink Figure 3}

A
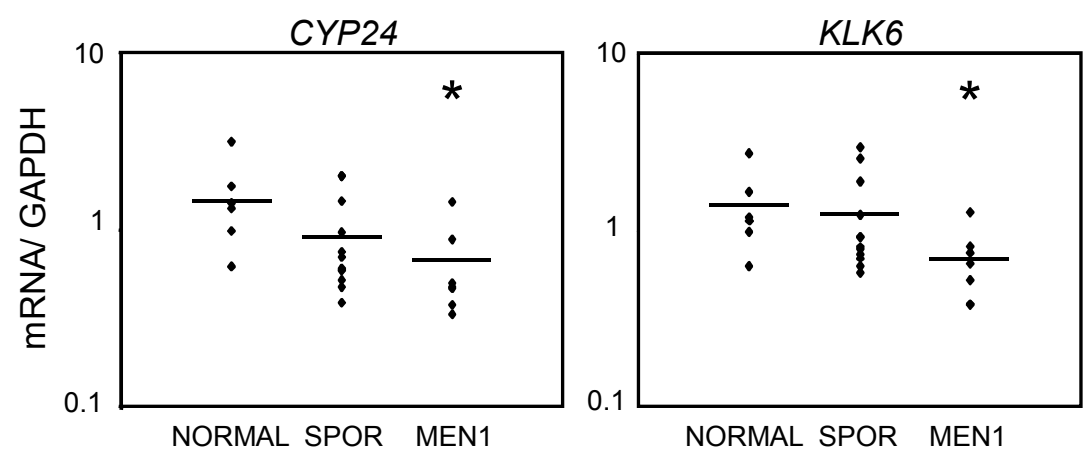

B
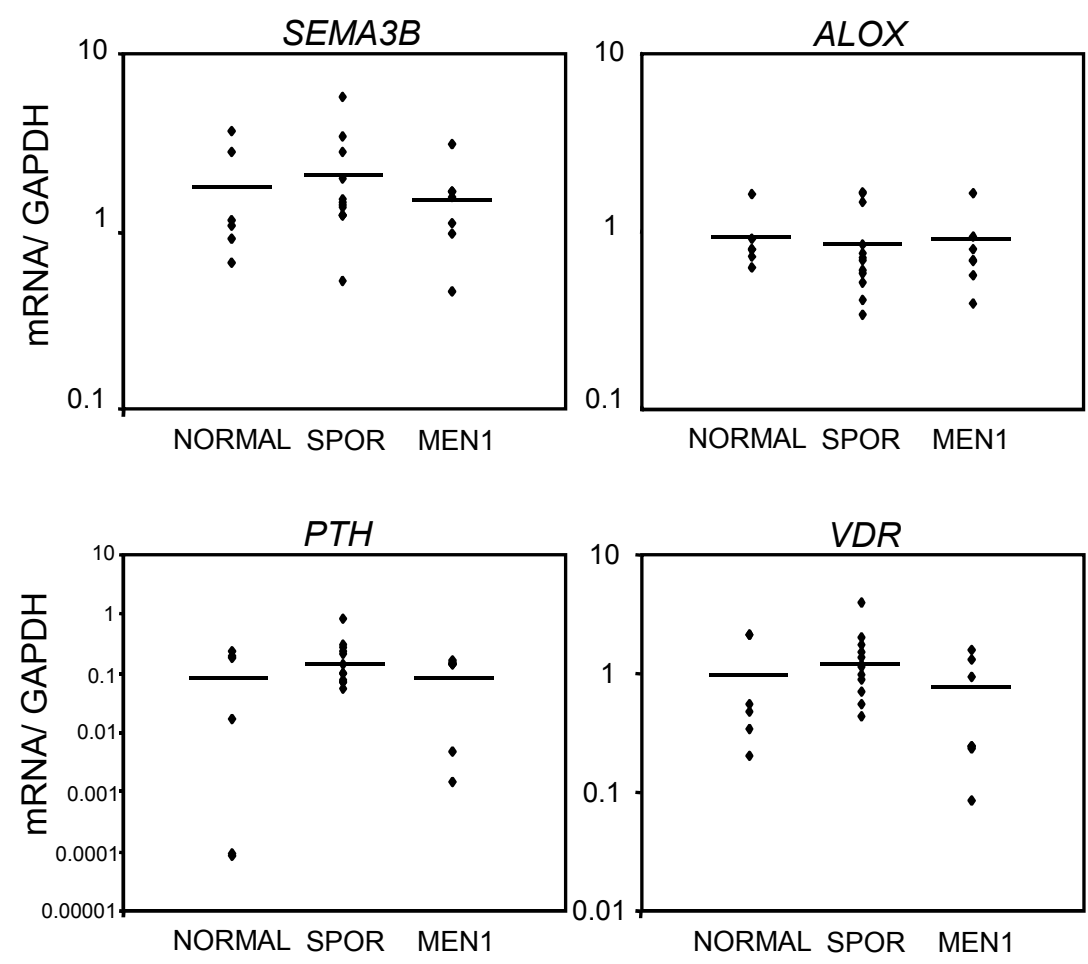


\section{Dreijerink Figure 4}
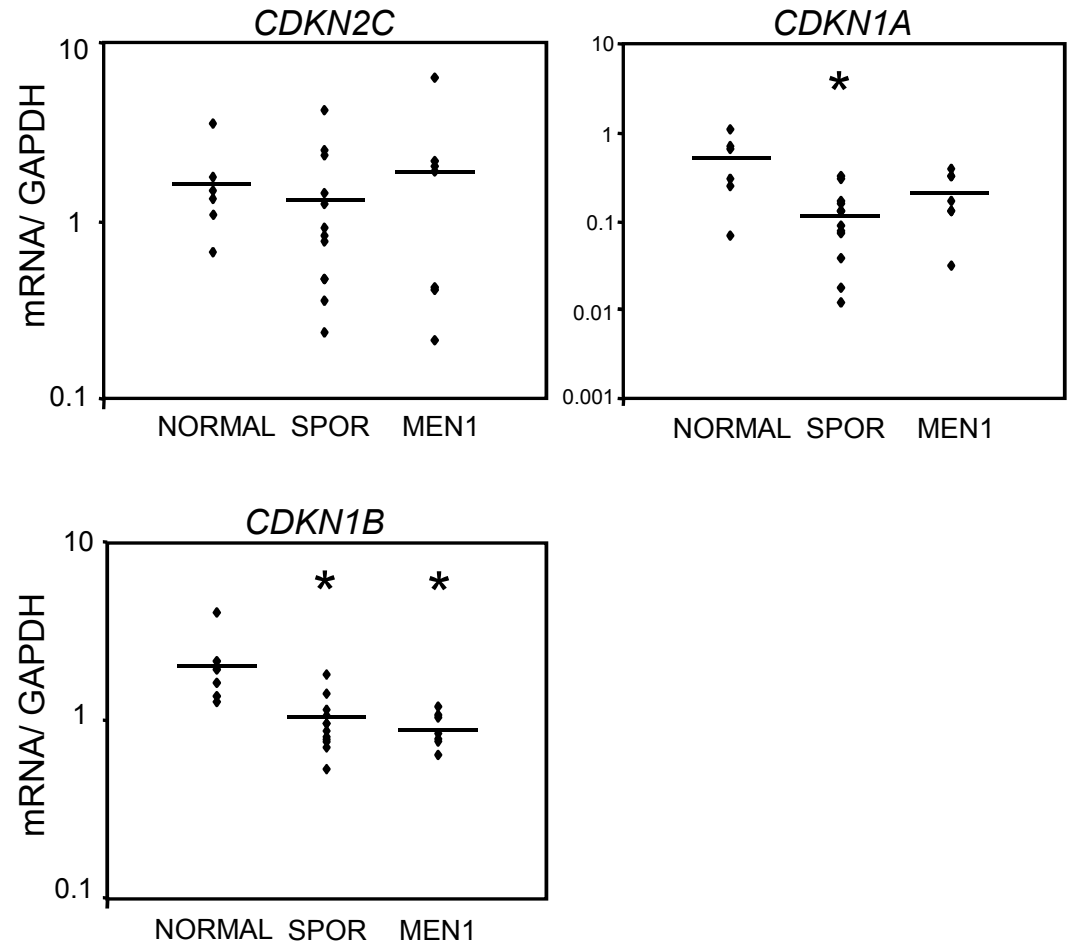